\title{
PEMANFAATAN ALAT PERMAINAN EDUKATIF ULAR TANGGA DALAM PENERAPAN PEMBELAJARAN TEMATIK DI KELAS III SD
}

\author{
Aini Indriasih \\ UPBJJ-UT Semarang \\ e-mail: aini@ut.ac.id
}

\begin{abstract}
Games as tools in education is one of the media-based simulation designed to stimulate the existing problems, in order to obtain the essence of science that can be used to solve the problem. This research was conducted with the purpose of implementing the thematicbased character education by utilizing the tools of educational games. The results of this study are expected to provide an alternative activity to play in learning process and cultivate children to skillfully handle the problem independently, encouraging teachers to be more creative in educating the children with media interest and in accordance with the children's development. This study used a quasi-experimental design. The data collection technique used was the test and observation guidelines. Implementation of research had been done in class III SD 02 Temulus in Distric of Kudus in central of Java. The research result showed that the activity of students in the learning was 84 which is very active. The result of learning process skills was 81 , while learning completeness score was 88 . The test results influenced the activity of the students' learning as big as 0,684. There was still 0,352 of variance which was influenced by other variables. The influence of skills in the learning process of students to the students test scores was 0,616. It means, there are other variables which influence the test scores as big as 0,384. Comparative tests between pretest and post-test ( $t$ test) was $t=12,2^{*}$, means that there was difference in learning outcomes before and after treatment.
\end{abstract}

Keywords: character education, educational games, thematic learning

\begin{abstract}
ABSTRAK
Alat permainan edukasi adalah salah satu media berbasis simulasi yang didesain untuk menstimulasikan permasalahan yang ada, sehingga diperoleh esensi ilmu yang dapat digunakan untuk menyelesaikan masalah. Penelitian ini dilakukan dengan tujuan menerapkan pendidikan karakter berbasis tematik dengan memanfaatkan alat permainan edukatif. Hasil penelitian ini diharapkan dapat memberikan alternatif kegiatan bermain sambil belajar dan membudayakan anak untuk terampil mengatasi masalahnya secara mandiri, mendorong guru untuk dapat lebih kreatif membelajarkan anak dengan media yang menarik dan sesuai dengan perkembangan anak. Penelitian ini menggunakan desain quasi eksperimen (eksperimen semu). Sedangkan teknik pengumpulan yang digunakan adalah tes dan pedoman observasi. Pelaksanaan penelitian dilakukan di kelas III SD 02 Temulus Kabupaten Kudus. Dari hasil penelitian diperoleh nilai keaktifan siswa dalam pembelajaran sebesar 84 dengan kriteria sangat aktif. Adapun nilai keterampilan proses dalam pembelajaran sebesar 81 dengan kriteria terampil, sedangkan ketuntasan belajar diperoleh skor 88. Dari hasil uji pengaruh keaktifan terhadap hasil belajar diperoleh skor 0,684 yang artinya masih ada pengaruh dari variabel lain sebesar 0,352 . Sedangkan pengaruh
\end{abstract}


keterampilan proses siswa dalam pembelajaran diperoleh skor 0,616 sehingga masih ada pengaruh variabel lain sebesar 0,384 . Uji banding sebelum dan sesudah perlakukan (uji t) diperoleh nilai $t=12.2<0.05$ dapat diartikan bahwa ada perbedaan hasil belajar sebelum dan sesudah perlakuan.

Kata kunci: pembelajaran tematik, pendidikan karakter, permainan edukatif

Kurikulum 2013 adalah kurikulum yang berbasis kompetensi. Dimana di dalamnya dirumuskan secara terpadu kompetensi sikap, pengetahuan, dan keterampilan yang harus dikuasai peserta didik. Adapun untuk lebih memudahkan pencapaian kompetensi yang dirumuskan maka dipilih pembelajaran tematik sebagai basis dalam pembelajaran. Pembelajaran tematik merupakan pendekatan pembelajaran yang didasarkan pada pemilihan tema yang sesuai dengan dunia anak sehingga menarik minat belajarnya. Adanya kesesuaian antara materi pembelajaran dengan dunia nyata dan minat belajar anak dapat mendorong anak untuk terlibat aktif dan mendapatkan kebermaknaan dalam proses belajar.

Pendekatan ini dimaksudkan sebagai suatu pembelajaran oleh seorang guru yang mengajar semua mata pelajaran di dalam kurikulum. Keefektifan pembelajaran tematik tidak lepas dari penggunaan suatu tema sebagai "pemersatu konsep" dan sebagai pelekat pengetahuan pada ingatan peserta didik (NREL, 2005). Di dalam praktiknya, pembelajaran tematik memiliki peluang untuk menginternalisasikan nilai-nilai dalam menyeimbangkan antara pencapaian hasil yang bersifat kognitif dan tingkah laku nyata, sehingga anak memiliki karakter sebagaimana dimaksud dari tujuan pendidikan.

Pendidikan yang kita idamkan adalah pendidikan yang menempatkan karakter di atas prestasi, bukan sebaliknya. Perolehan pengetahuan dan pengembangan karakter dapat dilakukan secara maksimal dalam kondisi pembelajaran yang bernuansa gembira, dan alat permainan sebagai medianya. Alat permainan edukatif, juga dikenal sebagai permainan pembelajaran dengan mengambil keuntungan dari prinsip dan teknologi permainan untuk menciptakan materi pendidikan. Bentuk awal dari alat permainan edukatif merupakan inkarnasi dari multimedia interaktif yang tergabung dalam permainan sederhana seperti teka-teki dan permainan mengingat sebagai alat yang digunakan untuk memberikan kesenangan dalam pembelajaran. (Tang dan Hanneghan, 2010: 10810)

Selama proses pembelajaran guru dituntut terampil dalam mengkaitkan kegiatan pembelajaran dengan konsep-konsep yang harus disajikan dalam suasana yang menyenangkan. Permainan selalu menjadi bagian dari alat yang digunakan guru sebagai teknik pembelajaran (Miller, 2008: 5). Bagi peserta didik di SD, suasana yang menyenangkan akan tercipta bila mereka belajar sesuai dengan dunia mereka, yaitu dunia bermain.

Permasalah penelitian ini adalah apakah keaktifan dan keterampilan proses siswa dalam proses pembelajaran tematik dengan alat permaian edukatif dapat berpengaruh positif terhadap peningkatan karakter siswa. Adapun tujuan penelitian ini adalah untuk melihat pengaruh positif manfaat alat permainan edukatif ular tangga terhadap peningkatan karakter siswa.

Belajar bertujuan untuk memperoleh dan menemukan struktur pemikiran umum yang dapat digunakan pada bermacam-macam situasi (Piaget dalam Winataputra, 2009), karena kita selalu menerima perubahan yang tidak terduga dan penemuan dalam hidup kita (Newman, 2012). Menurut Mintz (2012) dan Stengel (2010) dalam pemikiran pendidikan progresif mengatakan bahwa sekolah 
seharusnya memberikan pendidikan secara menyeluruh pada siswa (tidak hanya pemikiran), pembelajaran dipusatkan kepada siswa, daripada dipusatkan pada subjek/materi atau dipusatkan pada guru. Hal ini dikarenakan kepentingan dan kematangan dalam perkembangan anak terbatas dan menjadi penuntun dalam semua pembelajaran. Siswa harus terlibat secara aktif, cerdas, dan siswa harus memiliki motivasi dari dalam, sedangkan paksaan dari luar harus dihindari.

Pembelajaran yang terkait dengan ekperimen dan penemuan tidak hanya terus menerus dengan latihan atau menghafal, sehingga pembelajaran yang sesungguhnya akan lebih hidup, menyenangkan, dan tidak membosankan. Selanjutnya dapat ditegaskan bahwa dalam tindakan pembelajaran, sekolah harus memberikan pendidikan secara menyeluruh pada siswa, pembelajaran dipusatkan kepada siswa tidak hanya dipusatkan pada materi atau dipusatkan pada guru, karena kepentingan dan kematangan dalam perkembangan anak terbatas.

Bruner (dalam Winataputra, 2009) mengatakan bahwa belajar merupakan suara proses aktif yang memungkinkan manusia untuk menemukan hal-hal baru di luar informasi yang diberikan kepada dirinya. Proses belajar akan berlangsung secara optimal jika proses pembelajaran diawali dengan tahap enaktif yaitu tahap pembelajaran pengetahuan secara aktif, dengan menggunakan benda konkret atau situasi yang nyata, dilanjutkan dengan tahap ikonik yaitu tahap pembelajaran pengetahuan diwujudkan dalam bentu bayangan, gambar, atau diagram, dan diteruskan dengan tahap simbolik yaitu tahap pembelajaran pengetahuan yang diwujudkan dalam bentuk simbol-simbol abstrak. Oleh karena itu, proses pembelajaran akan berlangsung optimal bila siswa memperoleh sejumlah kegiatan mengolah bahan, mengerjakan soal, membuat kesimpulan, dan merumuskan suatu rumusan dengan kata-kata sendiri, dan secara kooperatif dengan siswa lain, dalam suasana lingkungan yang menyenangkan, dan dalam bimbingan guru.

Keaktifan siswa merupakan faktor utama dalam proses belajar dan keterampilan proses merupakan kemampuan siswa dalam memperoleh informasi, struktur pengetahuan, dan perkembangan dirinya, maka keaktifan dan keterampilan proses siswa pada penelitian ini diamati. Keberhasilan belajar tidak hanya dilihat dari kemampuan siswa menyelesaikan tes yang diberikan pada akhir suatu pembelajaran, tetapi perlu memperhatikan kemampuan siswa dalam mengikuti tahap-tahap pembelajaran. Jadi kemampuan yang ditunjukkan oleh siswa selama proses pembelajaran berlangsung, perlu dipertimbangkan untuk menentukan keberhasilan belajar siswa.

Siswa SD kelas III yang berada pada usia antara tujuh sampai sebelas tahun berada pada tahap operasional konkret. Dengan demikian guru hendaknya bisa membantu mengkonkretkan permasalahan ini dengan menggunakan media pembelajaran. Pada jenjang pendidikan di SD merupakan jenjang yang sangat penting dalam meningkatan sumber daya manusia (Syaodih, 2006). Pada jenjang inilah kemampuan dan keterampilan dasar dikembangkan pada peserta didik. Studi longitudinal yang dilakukan Bloom (Syaodih, 2006) memberikan gambaran bahwa prestasi akademik umum anak ditentukan oleh prestasi akademik anak pada akhir tahun kelas tiga SD. Temuan ini menggambarkan bahwa tahun-tahun pertama anak belajar di SD berpengaruh signifikan terhadap sikap dan pola pencapaian prestasi anak selanjutnya.

Penelitian ini menerapkan media yang dapat membantu siswa memahami materi dan penerapan pendidikan karakter dengan alat permainan edukatif berupa ular tangga. Alat permainan edukatif ular tangga sangat menarik. Salah satu kelebihan pokok adalah pada visualisasi yang menyenangkan dapat mengaktifkan semua indera siswa sehingga stimulasi yang masuk dapat dengan mudah dicerna, anak memperoleh pemahaman dan kebermaknaan bagi hidupnya. Permainan edukatif simulasi ular tangga bertujuan untuk membentuk kemandirian, karena 
merupakan media pembelajaran yang memiliki pola learning by doing. Berdasarkan pola tersebut siswa sebagai pemain dituntut untuk belajar sehingga dapat menyelesaikan masalah yang dihadapi.

Pembelajaran tematik merupakan pendekatan pembelajaran yang melibatkan beberapa mata pelajaran untuk memberikan pengalaman belajar yang bermakna bagi anak, karena berorientasi pada praktek pembelajaran yang sesuai dengan kebutuhan anak. Pembelajaran tematik secara efektif membantu anak menciptakan kesempatan membangun konsep-konsep yang saling berkaitan yang diikat oleh satu tema. Dengan demikian, pembelajaran tematik memberikan kesempatan pada anak untuk memahami masalah yang kompleks yang ada di lingkungan sekitarnya dengan pandangan yang utuh. Dengan demikian anak diharapkan memiliki kemampuan untuk mengidentifikasi, mengumpulkan, menilai, dan menggunakan informasi yang ada di sekitarnya secara bermakna, (Hernawan dan Resmini, 2009).

Penelitian ini dilakukan di kelas III SD 02 Temulus Kabupaten Kudus pada semester gasal tahun ajaran 2014/2015 yang berjumlah 27 siswa. Waktu pelaksanaannya bulan Juli sampai dengan Oktober 2014. Adapun temanya pengalaman dengan standar kompetensi melaksanakan norma yang berlaku di masyarakat. Dari kompetensi tersebut diharapkan siswa mengenal aturan-aturan yang berlaku dan dapat melaksanakannya di lingkungan masyarakat sekitar. Penelitian ini dikategorikan sebagai kuasi eksperimen dengan desain One Group Pre Tes Post Test. Data dalam penelitian ini dikumpulkan dengan menggunakan tes yaitu untuk mengukur aspek kognitif siswa dan pedoman observasi untuk mengamati aktivitas siswa dalam proses pembelajaran, khususnya mengukur aspek afektif yang merupakan perwujudan karakter.

\section{HASIL PENELITIAN DAN PEMBAHASAN}

Penelitian yang diadakan di SD 02 Temulus kecamatan Mejobo Kabupaten Kudus, proses pembelajarannya menggunakan alat permainan edukatif (APE) dengan beberan permaian ular tangga. Dimana hasil observasi diketahui bahwa siswa merasa senang dalam mengikuti proses pembelajaran. Hal ini dikarenakan siswa merasa pembelajaran bukan sebagai beban tetapi semacam bermain-main. Siswa mudah memahami materi yang diberikan guru yang dikemas dengan permainan. Permainan itulah yang merupakan suatu kegemaran dari para siswa SD yang memang masih suka akan bermain.

Prosedur permainan ini mengadopsi metode think phare and share, yang meliputi:

1. Tahap Berpikir, siswa dituntut berpikir sendiri terlebih dahulu dalam satu kelompok dengan mempelajari materi yang ada di kartu pintar masing-masing.

2. Tahap Berpasangan, siswa tanya jawab secara berpasang-pasangan dalam kelompoknya.

3. Tahap Berbagi, siswa dalam kelompok bertukar kartu pintar dan saling berbagi informasi dari apa yang telah dipelajari pada kartu pintarnya. Kemudian siswa berdiskusi untuk mengerjakan Lembar Kerja yang telah disediakan guru. Dalam mengisi LK, siswa dituntut untuk saling berbagi, informasi dari kartu pintar masing-masing yang telah dipelajari. Hal ini diharapkan memotivasi setiap siswa dalam kelompok untuk aktif berdiskusi.

4. Tahap Permainan, setiap siswa dalam kelompok memegang kartu monitoring teman di sampingnya. Kemudian sesuai kesepakatan dalam kelompok atau urutan mempersilahkan seorang siswa untuk memulai permainan dengan melemparkan dadu, sedangkan teman di sampingnya bersiap mengambil kartu pintar yang terdapat pada wadah yang sesuai dengan nomor yang ditampilkan dadu dan memberikan pertanyaan yang terdapat pada kartu pintar serta mengisi kartu monitoring sesuai jawaban yang diberikan siswa yang sedang bermain. Untuk jawaban benar pada kolom kartu monitoring dibubuhkan simbol B, sedangkan jika 
jawaban salah menggunakan simbol S. Setiap jawaban benar akan mendapatkan reward, jika salah akan mendapatkan hukuman sesuai aturan yang terdapat pada kartu pintar. Hal ini sekaligus akan menentukan nasib masing-masing siswa pada papan ular tangga. Kemudian siswa lainnya secara berurutan bergiliran melempar dadu, begitu seterusnya hingga semua kolom pada kartu monitoring terisi yang menandakan permainan berakhir. Hal yang perlu diperhatikan dalam melakukan tahap ini adalah aturan main, yaitu jika siswa menjawab salah maka ketika bertemu tangga tidak boleh naik sedangkan jika bertemu ular diharuskan turun tingkat. Maka begitupun sebaliknya, jika menjawab benar dan bertemu tangga harus naik sedangkan bila bertemu ular tidak perlu turun tingkat. Dengan aturan ini diharapkan dapat melatih ketelitian dan kejujuran siswa. Dengan demikian sekaligus akan ada pembentukan karakter siswa selama pembelajaran berlangsung. Begitu pula pelaksanaan yang dilakukan pada pembelajaran berikutnya dengan beberapa perbedaan terutama dari segi materi dan indikator sesuai RPP yang telah dibuat.

Dari hasil observasi diperoleh rata-rata keaktifan siswa pada pembelajaran sebesar $84 \%$, artinya pada saat pembelajaran dengan media edukatif ular tangga siswa menunjukkan kategori sangat aktif. Siswa aktif yang dimaksud baik dalam pembelajaran praktek maupun dalam diskusi, serta memberikan ide alternatif jawaban maupun aktif memberikan jawaban yang dibuat secara tertulis. Keaktifan reaksi belajar mandiri siswa termasuk aktif menulis daftar pertanyaan ataupun menulis rangkuman sederhana. Keaktifan partisipasi dalam diskusi kelompok ditunjukkan dengan aktif membantu teman menjawab pertanyaan ataupun mengajukan pertanyaan, serta aktif bekerja dan aktif memberi kesempatan teman kelompok. Keaktifan siswa dalam menanggapi hasil diskusi di antaranya aktif mengkomunikasikan jawaban untuk membantu teman yang belum mengerti juga berani memunculkan alternatif jawaban serta menunjukkan konsentrasi pada pembahasan masalah. Sikap keaktifan siswa dalam pembelajaran secara global termasuk aktif untuk menyelesaikan tugas dan membuat catatan materi, aktif menjawab soal menurut pendapatnya sendiri, aktif untuk bersikap serius dalam mengikuti pembelajaran, aktif untuk bersikap berani bertanya kepada teman dan guru apabila belum memahami.

Adapun hasil observasi keterampilan proses siswa dalam pembelajaran diperoleh $81 \%$, artinya setelah pembelajaran dengan media edukatif ular tangga, keterampilan proses siswa menunjukkan menunjukkan kategori terampil. Variabel keterampilan proses cenderung homogen. Keterampilan yang yang dikembangkan dalam pembelajaran ini adalah: keterampilan dalam pembelajaran secara umum, keterampilan bertanya, memahami materi yang diberikan guru melalui permainan, partisipasi dalam diskusi kelompok, keterampilan menyelesaikan tugas dalam permainan/pembelajaran, dan keterampilan menyelesaikan tugas.

Berdasarkan hasil perolehan di atas, siswa secara keseluruhan dapat dikategorikan memiliki keterampilan yang sama. Baik keterampilan dalam pembelajaran, reaksi belajar mandiri siswa, partisipasi dalam diskusi kelompok. Sikap reaksi siswa dalam menanggapi hasil diskusi maupun dalam pembelajaran secara global.

Hasil Belajar media edukatif ular tangga dapat dilihat pada Tabel 1. Pada hasil belajar berproses secara individu, untuk deskripsi variabel, diolah memakai software SPSS, maka mendapatkan hasil statistik output seperti pada Tabel 1.

Pada hasil belajar berproses diperoleh mean skor 88,03. Nilai mean itu diperoleh dari jumlah seluruh nilai hasil belajar tiap individu dibagi dengan banyaknya responden. Hal ini berarti bahwa responden yang terdiri dari siswa rata-rata cenderung mendapatkan hasil yang bagus dalam 
mengikuti pembelajaran. Hasil belajar termasuk kategori sangat memuaskan. Dengan demikian pembelajaran dengan media edukatif ular tangga dalam hal ini dikatakan efektif.

Tabel 1. Frequencies Statistics

\begin{tabular}{|l|rr|}
\hline \multicolumn{1}{|c|}{ Missing } & Valid & 27 \\
Mean & & 27 \\
Std Eror of Mean & & 88,9286 \\
Median & 1,6742 \\
Mode & 92,5000 \\
Std Deviation & 100,00 \\
Variance & 10,8502 \\
Range & 117,7265 \\
Minimum & 30,00 \\
Maximum & 70,00 \\
Sum & 100,00 \\
& & 3735,00 \\
\hline
\end{tabular}

Untuk mengetahui pengaruh keaktifan dan keterampilan siswa terhadap hasil belajar maka dilakukan dengan uji analisis regresi sederhana. Maka sebelum melakukan uji pengaruh dengan analisis regresi dilihat terlebih dahulu asumsi uji syarat kenormalan pada variabel dependen. Adapun analisis yang digunakan adalah analisis non parametric Kolmogorov-Smirnov. Hasil yang diperoleh adalah terlihat pada Tabel 2.

Tabel 2. Uji Normalitas Keaktifan One-Sample Kolmogorov-Smirnov Test

\begin{tabular}{|c|c|c|}
\hline & & $A K t$ \\
\hline$N$ & & 27 \\
\hline Normal Parameters ${ }^{a . b}$ & Mean & 90,000 \\
\hline & Std Deviation & 9,8154 \\
\hline Most Extreme & Absolute & 0,195 \\
\hline Differences & Positive & 0,154 \\
\hline & Negative & -195 \\
\hline Kolmogorov- Smirnov Z & & 1,262 \\
\hline Asymp Siq (2-tailed) & & 0,083 \\
\hline
\end{tabular}

a. Test distribution is Normal

b. Calculated from data

Data pada Tabel 2, menunjukkan nilai sig $=0,083$ atau 8,3 \% lebih dari 5\%. Hal ini berarti $H_{O}$ : diterima dengan demikian dapat disimpulkan bahwa data berdistribusi normal. Dari perhitungan, Coefficients, untuk mendapatkan persamaan regresi diperoleh Estimasi: $\hat{Y}=9,942+$ 9,381X. Maka untuk menguji bentuk persamaan regresi tersebut, dilakukan uji Anova yang hasilnya menunjukkan bahwa keaktifan siswa dalam pembelajaran dengan media edukatif ular tangga mempunyai hubungan linier terhadap hasil belajar, sehingga keaktifan siswa dalam proses pembelajaran memberi pengaruh terhadap hasil belajarnya. Dari uji tersebut diperoleh model Summary seperti pada Tabel 3. 
Tabel 3. Model Summary Variabel Keaktifan

\begin{tabular}{ccccc}
\hline Model & $R$ & $\begin{array}{c}R \\
\text { Square }\end{array}$ & Adjusted R Square & $\begin{array}{c}\text { Std Error of The } \\
\text { Estimate }\end{array}$ \\
\hline 1 & $0,805^{a}$ & 0,648 & 0,639 & 5,8988 \\
\hline
\end{tabular}

a. $\quad$ predictor (Constant).Akt

Data pada Tabel 3, menunjukkan nilai $R^{2}(R$ square $)=0,648$ atau $=64,8 \%$, artinya keaktifan siswa dalam pembelajaran mempengaruhi hasil belajar sebesar $64,8 \%$, dan $35,2 \%$ dipengaruhi variabel lainnya.

Tabel 4. Uji Normalitas One-Sample Kolmogorov-Smirnov Test

\begin{tabular}{llr}
\hline & & \multicolumn{2}{c}{ Tramp } \\
\hline$N$ & & 27 \\
Normal Parametersa,b & Mean & 75,0000 \\
& Std. Deviation & 7,09562 \\
Most Extreme Differences & Absolute & 0,222 \\
& Positive & 0,170 \\
& Negative & $-0,222$ \\
Kolmogorov-Smirnov Z & & 1,089 \\
Asymp. Sig. (2-tailed) & & 0,086 \\
\hline
\end{tabular}

a. Test distribution is Normal.

b. Calculated from data.

Data pada Tabel 4 menunjukkan nilai $s i g=0,086$ atau 8,6 \% lebih dari 5\%. Hal ini berarti $H_{O}$ : diterima dengan demikian dapat disimpulkan bahwa data berdistribusi normal. Dari perhitungan, Coefficients, untuk mendapatkan persamaan regresi diperoleh Estimasi: $\hat{Y}=15,453+$ $9,347 X$. Selanjutnya, dari hasil uji Anova, diperoleh nilai sig $(=0,000)<\alpha(=0,05)$, yang berarti bahwa $H_{O}$ ditolak atau $H_{1}$ diterima. Artinya keterampilan proses dalam pembelajaran mempunyai hubungan linier terhadap hasil belajar. Karena linear, maka dalam keadaan ini menunjukkan adanya pengaruh positif keterampilan proses dalam pembelajaran terhadap hasil belajar.

Tabel 4. Model Summary Variabel Keterampilan

\begin{tabular}{ccccc}
\hline Model & $R$ & $R$ Square & Adjusted $R$ Square & $\begin{array}{c}\text { Std Error of The } \\
\text { Estimate }\end{array}$ \\
\hline 1 & $0,785^{a}$ & 0,616 & 0,607 & 6,1548 \\
\hline
\end{tabular}

Dari Tabel 4, diperoleh informasi bahwa besar pengaruh keterampilan proses terhadap hasil belajar dapat dilihat pada nilai $R^{2}(R$ square $)=0,616$ atau $=61,6 \%$. Artinya keterampilan proses mempengaruhi hasil belajar sebesar $61,6 \%$, dan $38,4 \%$. dipengaruh variabel lain.

Uji beda ( $t$ test) dilakukan untuk menguji perbedaan hasil belajar ebelum dan sesudah perlakukan. Hasil uji t dapat diketahui dari asumsi aqual Varian assumed, diperoleh nilai $t=12,2 \mathrm{Sig}$ 
untuk uji $t$ sama dengan $0,000=0 \%$ lebih kecil dari $5 \%$ berarti signifikan maka $H_{O}$ ditolak, ada perbedaan antara kedua hasil belajar. Hasil yang didapat menunjukkan bahwa $\mu_{1}-\mu_{2}>0$ berarti $\mu_{1}>\mu_{2}, H_{O}$ ditolak, artinya dapat disimpulkan bahwa rata-rata hasil belajar siswa berbeda signifikan antara sebelum dan sesudah perlakuan.

Hasil observasi keaktifan siswa rata-rata secara individu menunjukkan kategori sangat aktif. Siswa berjumlah 27 terdapat 17 siswa kategori sangat aktif dan 10 siswa termasuk kategori aktif. Keaktifan ini terlihat dalam menggungkapkan pendapat, menjawab pertanyaan, membuat rangkuman, membantu teman, memberi kesempatan teman untuk aktif, menyelesaikan tugas. Hasilnya menunjukkan siswa sangat aktif. Terdapat sebanyak $62,96 \%$ siswa termasuk sangat aktif dan 37,04\% termasuk aktif. Kegiatan kelompok dan partisipasi dalam diskusi serta sikap reaksi siswa dalam kelompoknya menunjukkan kategori sangat aktif.

Demikian juga keterampilan proses siswa secara individu menunjukkan kategori sangat terampil. Siswa berjumlah 27 terdapat 15 siswa kategori sangat terampil dan 12 siswa termasuk kategori terampil untuk mengungkapkan pendapat, menjawab pertanyaan, membuat rangkuman, membantu teman, memberi kesempatan teman dan berusaha menyelesaikan soal dengan sebaikbaiknya, menyelesaikan tugas dan indikator lain yang hasilnya menunjukkan siswa terampil. Terdapat $64,3 \%$ termasuk sangat terampil dan 35,7\% termasuk terampil.

Adapun hasil belajar dengan media edukatif ular tangga dimana penyampaian pembelajaran dengan metode yang menarik menjadikan siswa menjadi aktif, karena ada unsur permainan dan menyenangkan. Dengan suasana belajar yang menyenangkan, maka hasil belajar siswa sangat memuaskan. Berdasarkan hasil yang diperoleh di atas dari 27 siswa ternyata dapat tuntas semua, berarti pembelajaran media edukatif ular tangga berhasil.

Hasil Analisis Regresi untuk mengetahui pengaruh keaktifan siswa terhadap hasil belajar. Dengan asumsi apabila siswa sangat aktif pada pembelajaran didapatkan hasil belajar yang memuaskan. Hal ini dapat dilihat perhitungan di atas bahwa: Keaktifan belajar mempengaruhi hasil belajar sebesar $64,8 \%$ sedangkan pengaruh variabel yang lain adalah sebesar $35,2 \%$. Maka dapat dikatakan bahwa pengaruh keaktifan siswa cukup besar terhadap hasil belajar siswa. Dengan demikian pembelajaran dengan media edukatif ular tangga dapat meningkatkan hasil belajar siswa, dan dapat mempengaruhi siswa menjadi aktif dalam belajar sehingga hasil belajar siswa menjadi sangat memuaskan. Dengan demikian untuk dapat menghasilkan belajar yang efektif apabila siswa dapat aktif dalam proses pembelajaran. Siswa dapat aktif apabila guru berhasil memberikan motivasi pada peserta didiknya sebagai contoh memanfaatkan media ular tangga.

Kemudian berdasarkan pengamatan dari observer didapatkan informasi bahwa dalam pelaksanaan penggunaan media ular tangga dapat membuat siswa menjadi lebih aktif, sehingga pembelajaran tidak berpusat pada guru, disini guru hanya berperan sebagai fasilitator. Meskipun dalam pelaksanaannya menimbulkan suasana ramai di kelas namun siswa terlihat antusias, sebab tanpa disadari sebenarnya dalam permainan yang mereka lakukan mereka sedang mengalami proses belajar, sehingga hal ini dapat menghapus anggapan bahwa belajar itu membosankan. Hal ini seperti yang dikemukakan Tang dan Hanneghan, (2010: 108-10) bahwa bentuk awal dari alat permainan edukatif merupakan inkarnasi dari multimedia interaktif yang tergabung dalam permainan sederhana seperti teka-teki dan permainan mengingat sebagai alat yang digunakan untuk memberikan kesenangan dalam pembelajaran.

Dalam pembelajaran ini terkandung suatu prinsip yang menyatakan bahwa diperlukannya kegiatan belajar bermain bagi siswa. Salah satu prinsip tersebut menurut Sulaimansyah (2011), 
adalah prinsip belajar sambil bermain, yang mengatakan bahwa bermain merupakan kegiatan yang dapat menimbulkan suasana gembira dan menyenangkan, sehingga akan dapat mendorong siswa untuk melibatkan diri dalam proses pembelajaran. Oleh karena itu, dalam setiap pembelajaran disarankan untuk menciptakan suasana yang menyenangkan melalui kegiatan bermain yang kreatif. Dari salah satu prinsip pembelajaran tersebut, nampak bahwa semuanya dalam rangka menciptakan suasana pembelajaran yang membuat siswa senang sehingga mereka akan terlibat aktif dalam pembelajaran. Pernyataan ini berbanding lurus dengan keadaan siswa dalam kegiatan belajar sambil bermain menggunakan ular tangga. Hasil observasi diperoleh bahwa setiap siswa terlihat lebih aktif dari biasanya serta terlihat senang atau lebih menikmati proses pembelajaran.

Selanjutnya salah satu usaha yang perlu dilakukan guru untuk menunjang penerapan prinsip belajar sambil bermain dalam mengelola pembelajaran, guru perlu menggunakan media dan sumber belajar yang bervariasi yang sesuai dengan tahap perkembangan anak, dan kreatif menghadirkan alat bantu pembelajaran serta mampu menyajikan kegiatan yang bervariasi sehingga tidak membuat siswa jenuh. Hal inilah yang ingin ditekankan dalam penggunaan media ular tangga, yaitu membuat siswa menikmati proses pembelajaran menjadi lebih bermakna.

Menurut pengamatan peneliti siswa berada dalam kondisi gembira. Hal ini terlihat dalam proses belajar sambil bermain menggunakan ular tangga, dimana meskipun siswa terlihat ramai namun mereka aktif dalam pembelajaran dan menikmati setiap prosesnya. Dari hasil catatan refleksi bahwa sebagian besar siswa merasa senang dan ingin belajar kembali menggunakan ular tangga. Kemudian peningkatan hasil belajar aspek kognitif ini menurut peneliti disebabkan kemampuan daya ingat siswa membaik. Permainan ini dapat juga meningkatkan aspek afektif anak. Hal ini dapat membuktikan pernyataan yang mengungkapkan bahwa dalam permainan ular tangga terdapat nilainilai karakter, di antaranya adalah nilai ketaatan pada aturan, kejujuran dan ketelitian. Demikian juga aspek afektifnya akan berkembang karakternya. Hal ini dapat dilihat dari siswa yang memiliki tanggung jawab akan dapat mencapai hasil belajar yang tinggi. Semakin besar tanggung jawab yang dimiliki seorang siswa akan semakin meningkatkan prestasi belajarnya.

Sejalan dengan penelitian yang dilakukan Berkowitz, dkk. (2008), bahwa sebagai dampak dari pelaksanaan pendidikan karakter yang efektif maka terjadi pada perbaikan iklim sekolah termasuk iklim pembelajaran, siswa berperilaku lebih santun, dan pro sosial, tindakan-tindakan yang tidak terpuji menurun secara drastis, motivasi akademik serta prestasi siswa naik secara signifikan, serta meningkatkan keterampilan siswa dalam pemecahan masalah dan mampu mengembangkan kompetensi emosionalnya. Dari dampak pembelajaran yang bermakna seperti memanfaatkan media ular tangga tersebut, salah satunya dapat membuat struktur kognitif yang diperoleh siswa sebagai hasil dari proses belajar bermakna akan stabil dan tersusun secara relevan dalam ingatan. Hal ini akan memudahkan siswa untuk mengingat kembali apa yang telah dipelajarinya jika siswa dihadapkan pada suatu masalah. Pengetahuan yang terdapat dalam ingatan dapat diperoleh kembali sewaktu-waktu. Dengan ini dibuktikan ketika guru mengajukan pertanyaan, siswa sebagian besar mampu menjawab dan masih mengingat materi sebelumnya. Maka dengan keadaan ini, tentunya akan memudahkan siswa dalam mengerjakan tes akhir sehingga hasil belajar aspek kognitifnya meningkat.

Hasil observasi diketahui bahwa terdapat peningkatan hasil belajar siswa pada aspek afektif, khususnya siswa mulai menampakkan sikap jujur, dimana diketahui sebelumnya bahwa pada awal pembelajaran terdapat banyak siswa yang kurang jujur saat bermain serta pengisian kartu yang diisi sendiri atau kerja sama dengan teman sehingga diisi benar semua, dengan harapan mendapat nilai yang bagus. Tetapi pada hari berikutnya siswa sudah menampakkan kejujuran dengan mengikuti 
aturan yang telah ditetapkan bersama. Hal ini dikarenakan sesama saling teman memonitor kegiatan yang dilakukan, dan yang lebih penting lagi adalah guru selalu mengingatkan bahwa kejujuran lebih penting dari nilai tes. Aspek ketelitian dapat dicapai melalui kegiatan mengingat prosedur permainan dan urutan cara bermain, dan masih ada lagi karakter yang terbentuk dari hasil pembelajaran ini.

Dengan demikian penerapan pembelajaran dengan media ular tangga (APE), dapat dikatakan sebagai sarana pembentukan karakter bagi siswa. Menurut Lickona (1991) esensi pendidikan karakter adalah: pendidikan yang akan dipertanggung jawabkan kepada Tuhan, bagaimana seharusnya manusia hidup bersama di dunia. Pendidikan karakter merupakan tugas utama sekolah, nilai-nilai umum pendidikan karakter untuk mencegah konflik di masyarakat, kandungan nilai-nilai demokratik, karakter apa yang harus melekat dalam pribadi berkarakter, indikator orang yang berkarakter, dan kemampuan yang harus ditunjukkan oleh anak-anak yang berkarakter. Dengan demikian anak dapat dikatakan berkarakter apa bila paham akan kebaikan, ingin selalu berbuat kebaikan, dan melakukan kebaikan.

Berkaitan dengan pendapat yang dikemukakan Lickona (1991), tentang esensi pendidikan karakter yang harus dipertanggungjawabkan kepada Tuhan. Dengan demikian pada penelitian ini ada sejumlah kegiatan antar lain: (1) materi yang diterapkan tentang mengenal aturan-aturan yang berlaku dan dapat melaksanakannya di lingkungan masyarakat sekitar. (2) dalam mengisi evaluasi harus jujur, (3) kerja kelompok, merupakan penerapan dari kehidupan bersama dan mencegah konflik, dan (4) menerapkan nilai-nilai demokrasi melalui kegiatan diskusi dan memberikan kesempatan orang lain berpendapat. Sehubungan dengan hal tersebut, Kagan (2003) menyarankan empat hal penting yang harus diberikan kepada siswa, yaitu: (1) kecerdasan emosi; (2) pendidikan karakter; (3) kebiasaan untuk sukses; (4) kecedasan majemuk. Dengan demikian maka penerapan alat permainan edukatif ular tangga tepat dijadikan alternatif sebagai media pembelajaran, karena dapat meningkatkan hasil belajar dari aspek kognitif, afektif, dan karakter anak.

\section{SIMPULAN}

Pembelajaran Tematik dengan menerapkan Alat Permainan Edukatif ular tangga dapat membuat siswa lebih aktif sehingga meningkatkan karakter dan prestasi belajar. Kesimpulan dari pembelajaran ini adalah: (1) keaktifan siswa saat pembelajaran menunjukkan kategori sangat aktif. Hal ini terlihat dari kegiatan dalam menjawab pertanyaan kartu pintar, dan mengisi kartu monitoring; (2) keterampilan proses siswa menunjukkan kategori sangat terampil, ini diketahui dari kegiatan menyelesaikan tugas LKS maupun pengisian kartu monitoring, untuk menilai aktifitas temannya; (3) kontribusi keaktifan siswa dalam pembelajaran berpengaruh terhadap hasil belajar, dengan nilai sig $64,8 \%$ sedangkan pengaruh variabel lain 35,2\%.; (4) keterampilan proses mempengaruhi hasil belajar sebesar 61,6\%, pengaruh variabel lain sebesar 38,4\% ; (5) Uji Beda menunjukkan rata-rata hasil belajar siswa berbeda signifikan antara sebelum dan sesudah perlakuan.

\section{Saran}

Beberapa hal yang dapat disarankan untuk guru dalam meningkatkan keaktifan, keterampilan, kejujuran, partisipasi dalam diskusi, dan sikap siswa dalam pembelajaran, serta karakter lainnya, adalah: (1) menerapkan alat peraga edukatif seperti ular tangga, sebagai suatu variasi pembelajaran; (2) guru diharapkan dapat menerapkan pendekatan yang menyenangkan dan konstekstual sehingga siswa tidak hanya belajar secara kognitif tetapi juga dapat menumbuhkan aspek afektif atau karakter dan psikomotornya. 


\section{REFERENSI}

Berkowitz., Marvin, (2008). Understanding Effective Character Education. Ontario: The Literacy and Numeracy Secretariat Capacity Building Series.

Hernawan, Resmini, \& Andayani. (2009). Pembelajaran Terpadu di SD. Jakarta: Universitas Terbuka. Kagan, Spencer, (2003). Addressing Take Life Skill Crisis. Kagan Online Magazine, Summer 2003 Lickona, Thomas. (1991). Educating for Character. New York: Bantam Book.

Miller, CT. (ed). (2008). Games: Purpose and potential in Education. Morehead, KY: Springer.

Mintz, A.I. (2012). The Happy and Suffering Students? Rousseau's Emile and The Path Not Taken in Progressive Education Thought. Educational Theory, vol. 62(3), 2012 @ Board of Trustees University of Illinois.

Newman, O. (2012). No Child Is An Island: Character Development and The Rights of Children. Educational Theory. Volume 62 Number 12012 @ Board of Trustees University of Illionis.

Stengel, B.S. (2010). Autonomy? Or Responsibility? Educational Theory, vol. 60(1) 2010@ Board of Trustees University of Illinois.

Sulaimansyah. (2011). Meningkatkan Motivasi Belajar Kelas I SD 004 Tarakan dengan Model Pembelajaran Quantum Teaching dalam Pelajaran IPA. [online].Tersedia:http://inspirasiwahanapendidikan.blogspot.com/2011/11/meningkatkanmotivasi-belajar-kelas-i.html [Oktober 2014].

Syaodih, N. (2006). Pendidikan Bagi Anak Usia Sekolah Dasar. Dalam Sumantri, M dan Nana Syaodih. Perkembangan Peserta Didik, hal 6.13. Jakarta: Penerbit Universitas Terbuka.

Winataputra, Udin. S. (2009). Teori Belajar dan Pembelajaran. Jakarta: Universitas Terbuka. 